\title{
Analysis of the residential mortgage market in the Ural Federal District
}

\author{
E.G. Zinovyeva ${ }^{1} \bowtie$, N.R. Balynskaya ${ }^{1}$, S.V. Koptyakova ${ }^{1}$, O.O. Akhmetzianova ${ }^{2}$ \\ ${ }^{1}$ Nosov Magnitogorsk State Technical University, Magnitogorsk, Russia; e-mail: ekaterina_7707@mail.ru \\ ${ }^{2}$ University of Science and Technology of China, Hefei, Anhui, China
}

\section{ABSTRACT}

The relevance of this study stems from the fact that it analyzes the current situation on the mortgage market in Russia: the influence of macro-economic factors causes a fall in collateral value, dramatic increase in mortgage default and poor performance of the Agency for Housing Mortgage Lending (AHML). The study is aimed at investigating the current state of residential mortgage lending on the regional level in Russia by focusing on the case of the Ural Federal District. The study considers the interests of all the participants of this market: individual borrowers, state authorities, financial and credit institutions engaged in mortgage lending. The study analyzes statistical data on the primary residential mortgage market in the Ural Federal District provided by the Central Bank of the Russian Federation, Federal State Statistics Service and the AHML. Results. Modern approaches to mortgage system evaluation are compared in order to identify and systematize the key criteria and statistical indicators characterizing the current state of this form of lending relationships. The analysis also brings to light the negative trends in mortgage lending in the Ural Federal District. As a part of our further research, we are going to develop a procedure for evaluating the performance of a mortgage system.
\end{abstract}

\section{KEYWORDS}

residential mortgage, primary mortgage market, lenders, balanced autonomy model, single-tier and two-tiered models, mortgage institutions, lending market

\section{FOR CITATION}

Zinovyeva, E.G., Balynskaya, N.R., Koptyakova, S.V., \& Akhmetzianova, O.O. (2020). Analysis of the residential mortgage market in the Ural Federal District. R-economy, 6(1), 5-13. doi: 10.15826/recon.2020.6.1.001

\section{Анализ состояния рынка ипотечного жилищного кредитования в Уральском федеральном округе}

\author{
Е.Г. Зиновьева ${ }^{1} \bowtie$, Н.Р. Балынская ${ }^{1}$, С.В. Коптякова ${ }^{1}$, О.О. Ахметзянова ${ }^{2}$ \\ ${ }^{1}$ Магнитогорский государственный технический университет им. Г.И. Носова, Магнитогорск, Россия; \\ e-mail:ekaterina_7707@mail.ru \\ ${ }^{2}$ Научно-технический университет Китая, Хэфэй, Китай
}

\begin{abstract}
АННОТАЦИЯ
Актуальность статьи обусловлена тем, что макроэкономическая ситуация последних лет оказала самое серьезное влияние на быстроразвивающуюся систему ипотечного кредитования в Российской Федерации, обнажив целый комплекс проблем - падение стоимости залога, резкий рост просроченной задолженности по выданным ипотечным кредитам, низкая эффективность работы Агентства по ипотечному и жилищному кредитованию. Цель исследования - проанализировать состояние ипотечного жилищного кредитования в региональном разрезе на примере Уральского федерального округа, учитывая интерес всех участников: населения, государства и финансово-кредитных институтов, имеющих в распоряжении временно свободные денежные средства и предоставляющие их во временное пользование. Исследование базируется на аналитическом обзоре статистической информации, характеризующей первичный рынок ипотечного жилищного кредитования в Уральском федеральном округе. Информационно-эмпирическую базу исследования составили статистические материалы Центрального банка Российской Федерации, Федеральной службы государственной статистики, официальные отчетные данные Агентства по ипотечному и жилищному кредитованию. Результаты. По итогам сравнительного анализа многообразия подходов к оценке эффективности функционирования системы ипотечного кредитования определены и систематизированы основополагающие критерии и статистические показатели, характеризующие качество данной формы кредитных отношений; выявлены негативные тенденции, характерные для системы ипотечного кредитования Уральского федерального округа. В рамках дальнейшего исследования будет предложен алгоритм функционирования системы ипотечного кредитования.
\end{abstract}

(๑) Zinovyeva, E.G., Balynskaya, N.R., Koptyakova, S.V., Akhmetzianova, O.O., 2020

\section{КЛЮЧЕВЫЕ СЛОВА}

ипотечное жилищное кредитование, первичный рынок ипотечного жилищного кредитования, кредитные организации, модель сбалансированной автономии, одноуровневая и двухуровневая модель, ипотечные институты, кредитный рынок

\section{ДЛЯ ЦИТИРОВАНИЯ}

Zinovyeva, E.G., Balynskaya, N.R., Koptyakova, S.V., \& Akhmetzianova, O.O. (2020). Analysis of the residential mortgage market in the Ural Federal District. R-economy, 6(1), 5-13. doi: 10.15826/recon.2020.6.1.001 


\section{Introduction}

The recent macro-economic situation has had a considerable effect on the rapidly growing mortgage lending system in Russia, causing a fall in collateral value, a dramatic increase in mortgage default and poor performance results of the Agency for Housing Mortgage Lending (AHML). Nevertheless, despite these negative conditions, the experience of developed countries shows that in a market economy, this form of credit relationships is one of the key instruments to handle socio-economic problems and ensure the affordability of housing.

Mortgage market contributes to the development of a competitive economy, its stabilization and modernization, it also helps decrease inflation and social tension by proving people with housing and stimulating construction and other industries, by stabilizing the financial market and enhancing investment.

Mortgage lending can differ from country to country due to differences in their socio-economic development, financial and credit systems, legislation regulating mortgage relationships and the corresponding models of such relationships.

In Denmark, most mortgages have been provided by one of the major mortgage banks for 150 years. In Germany, loans are offered not only by mortgage banks but also by building societies

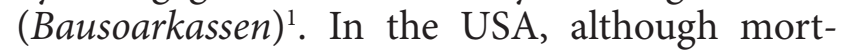
gages are issued by commercial banks, savingsand-loan associations, and credit unions, it is the government sponsored enterprises (GSEs) established by the US Congress which hold a significant part of the national mortgage portfolio ${ }^{2}$.

In the process of building a comprehensive residential mortgage system of its own, Russia can benefit from the experience of mortgage lending services accumulated by foreign banks. Comparative analysis of international models of mortgage lending can provide us with insights about the model that may hold most promise for Russia. In this article, we are also going to explore the current state of mortgage lending in Russian regions by focusing on the case of the Ural Federal District, in particular by looking at the interests of the key participants of the mortgage market: indi-

${ }^{1}$ Getting a mortgage in Germany. Expatica site. Retrieved from: http://www.expatica.com/de/housing/How-toget-amortgage-in-Germany 740222.html (19.04.2017).

2 Compare Mortgage Options. U.S. Bank National Association site. Retrieved from: https://www.usbank.com/homeloans/mortgage/compare-mortgage-options.aspx (19.04.2017). vidual borrowers, state authorities, financial and credit institutions engaged in mortgage lending.

This general aim comprises the following specific objectives: we are going to consider the existing models of mortgage lending in different countries (USA, Canada, UK and Germany); investigate the main challenges faced by the mortgage lending system in Russia; and conduct a comprehensive analysis of the primary mortgage market and its efficiency by using the case of the Ural Federal District.

As for the practical implications of this study, the described model of mortgage lending can be used by regional authorities in strategizing and decision-making in the sphere of socio-economic development of their respective regions. Our findings can also be useful for devising ways of stimulating housing construction through policy-making and legislation. Our research can be of interest to housing construction companies seeking to enhance their cooperation with the regional authorities. The results of this study can be used for rationalization of the use of funds in Russian regions and municipalities and their reallocation to address issues in the sphere of housing construction as a part of regional socio-economic policies.

\section{Conceptual and methodological framework}

The conceptual and methodological framework of this study is based on classical and contemporary, theoretical and applied research works on mortgage lending written by Russian and international scholars. It also relies on the main legal acts regulating lending relationships in general and mortgage lending in particular.

At the centre of our study is the category 'model of mortgage lending', which corresponds to specific aspects of mortgage lending in different countries determined by their socio-economic development, financial and credit systems, and laws governing mortgage lending. It should be noted that the model of mortgage lending is usually understood as a set of characteristics and relationships within the system of mortgage lending in a specific country [1].

In international practice, there are two basic models of attracting funds to the sphere of mortgage lending: these are single-tier (European countries) and two-tiered (USA, UK and Canada) models [2]. In both models funds are attracted by means of refinancing of mortgage markets 
through assignment of home loans by secondary market operators and securitization ${ }^{3}$. For all the local variations, mortgage lending tends to follow some general patterns, which can be described as three basic models: contractual-savings, secondary market model (or American model) and mortgage bank model [3; 4].

As the experience of developed countries shows, rational state policy in the sphere of mortgage lending may ensure the transformation of this sphere into a self-financing sector, capable of providing stable development of a housing market. Mortgage serves as a catalyst of the real estate market and interconnected spheres since growth in effective demand for housing stimulates construction, manufacturing of building materials and equipment as well as innovation in architecture. It also contributes to growth of retail industry and enhances employment rates [5].

In developed countries, the mortgage mechanism of housing acquisition is prioritized by the state socio-economic policy due to its efficiency: it helps attract considerable investment to the real sector of economy by encouraging housing construction. Moreover, affordable mortgages help the state meet the housing needs of its citizens. A long history of mortgage lending has resulted in the appearance of three classical models [6; 7]: truncated-open, balanced-autonomous and expanded-open. Let us consider them in more detail:

1. The balanced autonomous model (contractual savings system) is a model of mortgage lending based on the loan and savings principle similar to private building societies such as German Bausparkasse, French Livret Epargne Logement, and American savings and loans. The total portfolio of credit resources is formed not from the funds attracted on the open capital market but from the savings of future borrowers following the same principle as mutual funds [8]. In this model, lenders are not only mortgage banks, but also specialized savings banks such as building societies and savings banks [9]. An essential element of this model is the housing contractual savings, exceedingly wide spread in Germany, France, and Australia. Recently, they have also come in use in the new EU member states such as the Czech

3 Want A Mortgage? Forbes site. Retrieved from: https:// www.forbes.com/sites/nickclements/2016/09/30/want-amortgagethe-credit-score-used-by-mortgage-companies-willsurprise-you (19.04.2017).
Republic, Croatia, Slovakia and Hungary ${ }^{4}$. Apart from Europe, this model is also applied in Angola, Indonesia, Morocco, Thailand, Tunisia, and Chile.

We believe, however, that the balanced autonomous model is not well-suited for Russia for the following reasons: first, it limits the amount of attracted funds to the savings of contributors interested in obtaining credits for buying or building homes and does not include savings and resources of other economic entities; and second, inflation makes it impossible to set acceptable mortgage rates [10].

$2)$. The truncated-open model (traditional, single-tier) is limited to the primary market of mortgage lending where lenders receive mortgage bonds from their clients and use them as security to attract external investment. This model is typical of Western Europe (the UK, France, Denmark, and Spain), Eastern Europe (Bulgaria, Poland and Hungary), Israel, Australia and some Latin American countries. In EU countries, however, mortgage rates vary significantly (the difference can be more than two times) $[11 ; 12]$ ).

In Spain, the terms and conditions of a mortgage credit are the most liberal in Europe: a buyer can borrow up to $100 \%$ of the property's value for up to 35 years, with the mortgage origination fee of $1.5 \%$ of the property value. However, if a buyer decides to use a construction mortgage, they could save up to a half of the origination fee [13]. In France, a typical mortgage allows a buyer to borrow up to $80 \%$ of the property's value for up to 25 years. French banks' lending standards are generally more conservative than in some other European countries and the recent cuts to subsidized interest-free loans for home purchasing have changed the situation as banks started to raise their mortgage lending standards [14]. In the UK, the loan to value ratio is up to $70 \%$ while the mortgage rates continue falling and at the moment are at the level of $3.14 \%$. The minimum down payment is about $15 \%$ of the property's value [15].

Although the truncated-open (traditional, single-tier) model of mortgage lending is a prototype of the market model of lending relationships, we believe that it would not be a good fit to the Russian national context.

A key characteristic of the truncated-open model is the direct dependence of mortgage rates on the general state and stability of the country's economy, which also affects mortgage banking

${ }^{4}$ Top 5 countries with the lowest mortgage rates. Tranio site. Retrieved from: https://tranio.com/switzerland,japan,finland,germany,luxembourg/analytics/top 5 countries with the lowest mortgag e rates 5108/ (19.04.2017). 
activities in specific favourable and unfavourable periods. In practice, within this model, there are no universal standard parameters of mortgages, instead such parameters as the costs and terms of home loans are usually set by each individual mortgage bank depending on specific conditions.

While the scope of mortgage service is limited in Russia, the mortgage rates tend to be higher and the mortgage terms are shorter than in its European counterparts.

3. The expanded open model (model of the secondary mortgage market, two-tiered) is also commonly referred to as the 'American mortgage model' because it is the most popular in the US ${ }^{5}$ [16]. The primary mortgage market is where borrowers can obtain home loans directly from primary lenders while the secondary market deals with sales of securities or bonds collateralized by the value of mortgage loans.

The expanded open model means that a person with a certain annual income purchases a move-in ready home paying in cash only an insignificant part of its value (10-20\%) while the rest is borrowed from a specialized mortgage bank with the borrower's property (either already owned or being purchased) used as a collateral (at the interest rate of 7-9\%). As a rule, it takes about 15-30 years to repay such mortgage loans depending on the borrower's annual income and the mortgage type.

Within this model, the primary lender can refinance the issued mortgages either by selling them directly to investors or specialized institutions of the secondary market (secondary market operators) or by exchanging them for mortgage-backed securities $[17 ; 18]$.

The expanded open model is more suitable for the Russian context since, unlike the contractual savings system, it does not require much time for the accumulation of natural persons' funds in the initial period [19]. This means that the expanded open model can be implemented much faster and on a massive scale.

Our analysis of different models of mortgage lending has led us to the conclusion that the expanded open model is optimal for Russia (Figure 1) and that it will help make housing more affordable and accessible for Russian citizens.

Since this model is open and oriented towards obtaining resources from the free market, it is quite

\footnotetext{
${ }^{5}$ Homebuying Step by Step. Canada Mortgage and Housing Corporation site. Retrieved from: https://www.cmhcschl. gc.ca/en/co/buho/step-by-step/index.cfm (19.04.2017).
}

susceptible to changes in the financial and credit market. The stability of the system, however, is ensured by the government through legal, financial and licencing regulation. The government can also give guarantee and insurance against risks, provide tax preferences and offer targeted subsidies.

It should be noted that the structure of the current legal framework for mortgage lending in Russia is oriented towards building a secondary mortgage market, that is, it relies on the expanded open model. This becomes obvious if we look at Chapters 3 and 8 of the Federal Law 'On Mortgage (Pledges of Immovable Property)', describing the mortgagee's rights to the obligation secured by mortgage, assignment of rights under mortgage agreement, transfer and pledge of encumbrance.

The two-tiered scheme of mortgage lending in Russia was officially adopted in the 'Concept of the Development of the Residential Mortgage System', which launched the implementation of a consistent government policy aimed to ensure the rights of lenders and investors on the mortgage market and at the same time to make housing and mortgages more affordable and accessible for creditworthy citizens.

The two-tiered model of mortgage lending underpinning the Russian residential mortgage system holds considerable potential for state regulation of this market and, consequently, the real estate market, securities market and macro-economic regulation in general [1].

\section{Results and discussion}

The main focus of this study is the financial, economic, institutional and legal relationships in the residential mortgage market in Russia. At the key stage of this study we analyzed the available statistical data on the primary mortgage market in Russian regions [20; 21]. The data we used at this and the following stages of analysis were provided by the Central Bank of the Russian Federation, Federal State Statistics Service (Rosstat) and AHML in 2014-2018.

${ }^{6}$ The Decree of the Government of the Russian Federation of 11.01.2000 № 28 (amended as of 08.05.2002) 'On the Measures for the Development of the Residential Mortgage System in the Russian Federation' (together with the 'Concept of the Development of the Residential Mortgage System in the Russian Federation' and the 'Plan of Preparation of the Drafts of Regulatory Acts for the Development of the Residential Mortgage System in the Russian Federation'). Retrieved from: http://www.consultant.ru/cons/cgi/online. cgi req $=$ doc $\&$ base $=$ LAW $\& n=36649 \&$ fld $=134 \&$ dst $=10000$ $\underline{00001,0 \& \mathrm{rnd}=0.8203381367685081 \# 049319826734995775}$ (02.03.2020). 


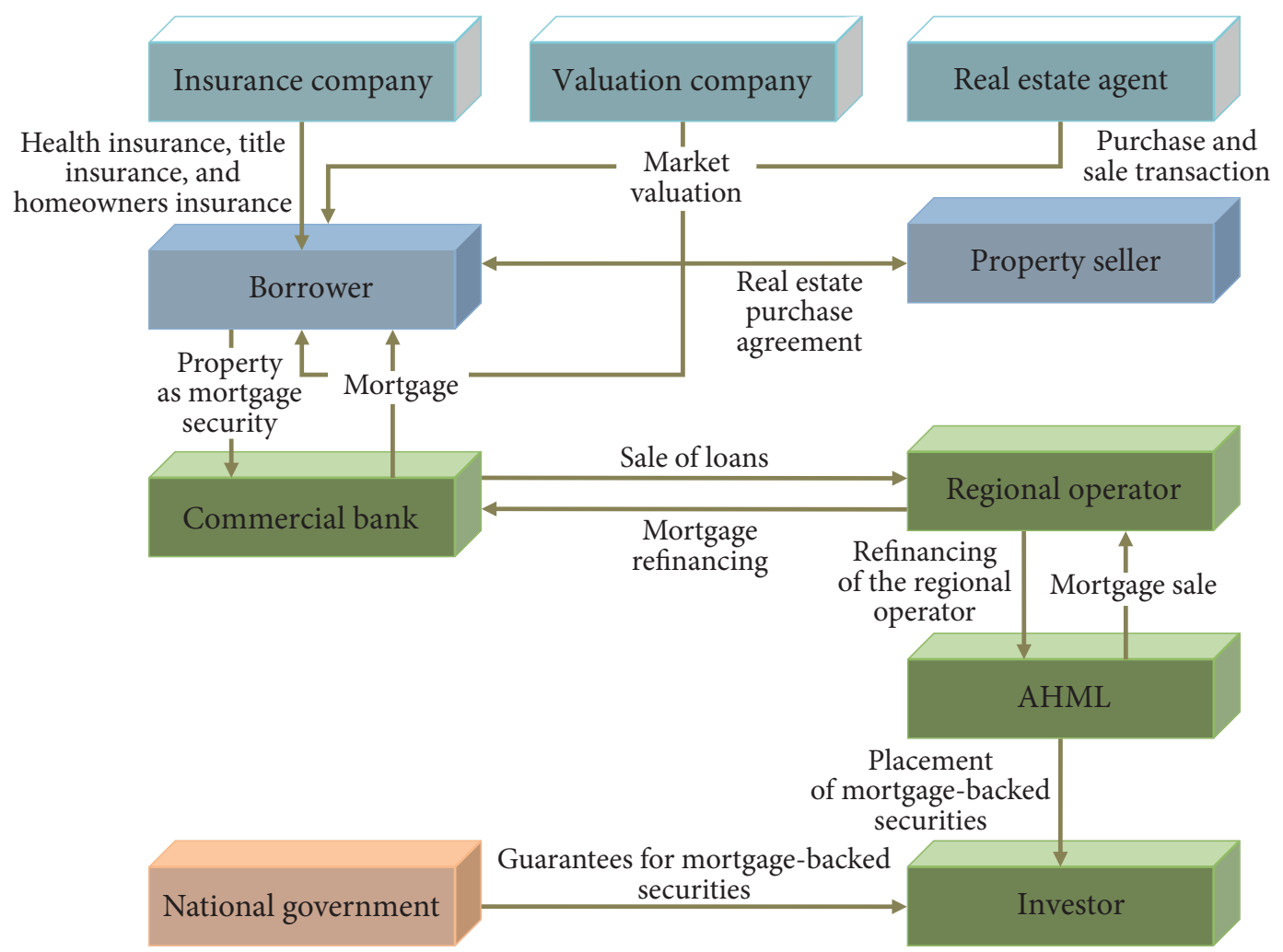

Figure 1. Expanded open model (secondary, 2-tiered) of mortgage lending in Russia [3]

If we look at the statistics on the number of lenders on the primary mortgage market in the Ural Federal District, we see the following picture: in the given period, the Central Bank's policy led to a decline in the number of lenders, including mortgage lenders; falling national currency value on the global market; and reduced demand for banking products (see Table 1).

Table 1

Number of lending institutions on the mortgage market of the Ural Federal District in 2014-2018

\begin{tabular}{|c|c|c|c|c|c|}
\hline \multirow{2}{*}{ Year } & \multicolumn{5}{|c|}{ Number of lenders, } \\
\cline { 3 - 6 } & total & \multicolumn{5}{|c|}{ including: } \\
\cline { 3 - 6 } & & $\begin{array}{c}\text { mortgage } \\
\text { lenders }\end{array}$ & $\begin{array}{c}\text { mortgage } \\
\text { investors }\end{array}$ & $\begin{array}{c}\text { mortgage } \\
\text { refinance } \\
\text { lenders }\end{array}$ & $\begin{array}{c}\text { lenders attract- } \\
\text { ing secondary } \\
\text { market investors }\end{array}$ \\
\hline 2014 & 35 & 34 & 9 & 1 & 6 \\
\hline 2015 & 32 & 31 & 8 & 0 & 3 \\
\hline 2016 & 29 & 28 & 8 & 1 & 1 \\
\hline 2017 & 26 & 26 & 9 & 4 & 3 \\
\hline 2018 & 23 & 23 & 10 & 8 & 3 \\
\hline
\end{tabular}

Compiled by the authors based on the AHML data. Retrieved from: https://cbr.ru/statistics/pdko/Mortgage/ (Accessed: 02.03.2020)

In 2014-2018, 11 lenders left the primary mortgage market, that is, the number of participants fell by $32.3 \%$, from 35 to 23 .

According to Figure 2, Sverdlovsk region had the maximum number of lenders on the mortgage market in 2014 (15 participants). In 2016, this region accounted for the largest share (45\%) in the total number of lenders in the Ural Federal District. In 2014-2018, Kurgan region had the smallest number of lenders on the mortgage market.

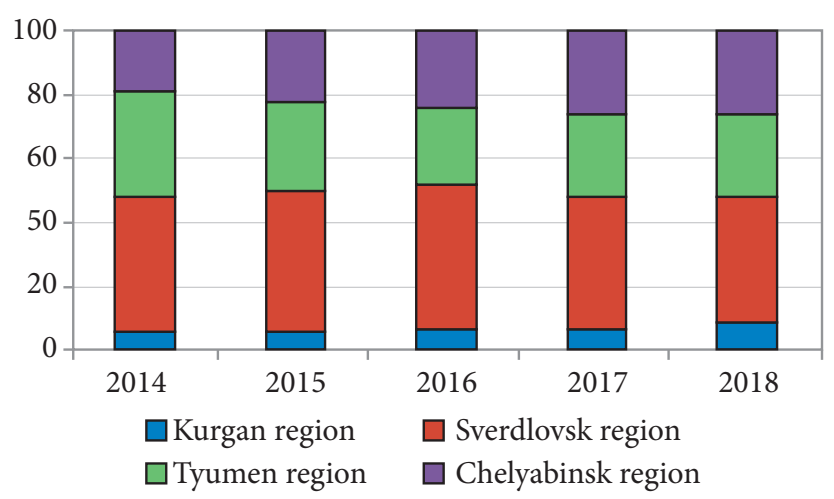

Figure 2. Structure of the mortgage market in the Ural Federal District in 2014-2018

Compiled by the authors based on the AHML data. Retrieved from: https://cbr.ru/statistics/pdko/Mortgage/ (Accessed: 02.03.2020)

The regional distribution pattern of issued mortgages in the given period remained practically the same. Borrowers in Tyumen region accounted for the largest volume of issued mortgages and, accordingly, the highest percentage in the overall volume of operations on the mortgage 
market in 2014-2018. The lowest figures were supplied by Kurgan region and the Yamalo-Nenets Autonomous District (Figure 3).

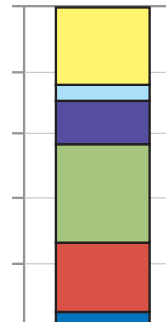

2014

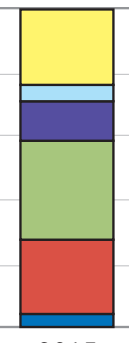

2015

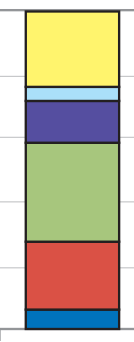

2016

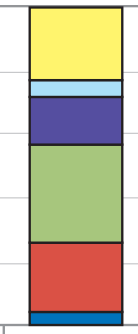

2017

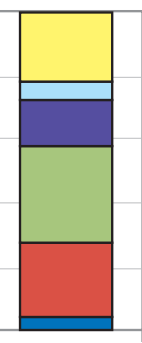

2018 $\square$ Kurgan region

$\square$ Tyumen region

$\square$ Sverdlovsk region

$\square$ incl. Khanty-Mansiysk AR

$\square$ Chelyabinsk region

Figure 3. Volume of mortgage loans given

to natural persons in 2014-2018

in the Ural Federal District

Compiled by the authors based on the AHML data.

Retrieved from: https://cbr.ru/statistics/pdko/Mortgage/

(Accessed: 02.03.2020)
The dynamics of the volume of mortgage lending shown in Figure 3 determined the dynamics of mortgage debt, which grew steadily in 2014-2018. As of the end of 2018, the amount of mortgage debt in roubles increased by 18,743 roubles (by 117.5\%) in comparison with 2014 and reached 125,792 roubles.

This situation to a significant extent was determined by per capita income in the region (Table 2).

In the Ural Federal District, per capita income increased from 28.7 thousand roubles a month in 2013 to 34.9 thousand roubles a month in 2018. According to Rosstat, the Yamalo-Nenetsk Autonomous Region ranked first among other Ural regions in 2018 in terms of per capita income and its dynamics (79.3 thousand roubles a month) while the poorest region, lagging behind the rest, is Kurgan region with per capita income of 20.3 thousand roubles a month.

Per capita income in the Ural Federal District, rbs

\begin{tabular}{|c|c|c|c|c|c|c|}
\hline Regions & 2013 & 2014 & 2015 & 2016 & 2017 & 2018 \\
\hline Ural Federal District & 28719 & 29997 & 32794 & 32907 & 33643 & 34955 \\
\hline Kurgan region & 17076 & 18315 & 20310 & 20175 & 20660 & 20334 \\
\hline Sverdlovsk region & 30459 & 31538 & 34113 & 34718 & 35210 & 36735 \\
\hline Tyumen region & 36167 & 37783 & 41893 & 42657 & 44241 & 46124 \\
\hline Khanty-Mansiysk Autonomous Region - Yugra & 39882 & 40811 & 46221 & 46934 & 48834 & 50717 \\
\hline Yamalo-Nenets Autonomous Region & 58829 & 62020 & 67624 & 72358 & 76027 & 79398 \\
\hline $\begin{array}{l}\text { Tyumen region without autonomous regions } \\
\text { (Khanty-Mansiysk and Yamalo-Nenets) }\end{array}$ & 23169 & 25142 & 27448 & 27044 & 27672 & 29162 \\
\hline Chelyabinsk region & 21971 & 23070 & 24654 & 23657 & 23719 & 24386 \\
\hline
\end{tabular}

Compiled by the authors on the basis of Rosstat data. Retrieved from: https://www.gks.ru/free doc/new site/population/urov/ urov 11sub.htm (Accessed: 02.03.2020)

Table 3

Weighted average period and rate of mortgages in roubles given to natural persons in 2014-2018 in the Ural Federal District

\begin{tabular}{|c|c|c|c|c|c|c|c|c|c|c|}
\hline \multirow[b]{2}{*}{ Region } & \multicolumn{2}{|c|}{2014} & \multicolumn{2}{|c|}{2015} & \multicolumn{2}{|c|}{2016} & \multicolumn{2}{|c|}{2017} & \multicolumn{2}{|c|}{2018} \\
\hline & \begin{tabular}{|} 
Weighted \\
average \\
mort- \\
gage \\
period, \\
months
\end{tabular} & $\begin{array}{l}\text { Weighted } \\
\text { average } \\
\text { rate, \% }\end{array}$ & $\begin{array}{c}\text { Weighted } \\
\text { average } \\
\text { mort- } \\
\text { gage } \\
\text { period, } \\
\text { months }\end{array}$ & $\begin{array}{c}\text { Weighted } \\
\text { average } \\
\text { rate, \% }\end{array}$ & $\begin{array}{l}\text { Weighted } \\
\text { average } \\
\text { mort- } \\
\text { gage } \\
\text { period, } \\
\text { months }\end{array}$ & $\begin{array}{c}\text { Weighted } \\
\text { average } \\
\text { rate, } \%\end{array}$ & $\begin{array}{l}\text { Weighted } \\
\text { average } \\
\text { mort- } \\
\text { gage } \\
\text { period, } \\
\text { months }\end{array}$ & $\begin{array}{c}\text { Weighted } \\
\text { average } \\
\text { rate, } \%\end{array}$ & $\begin{array}{l}\text { Weighted } \\
\text { average } \\
\text { mort- } \\
\text { gage } \\
\text { period, } \\
\text { months }\end{array}$ & $\begin{array}{c}\text { Weighted } \\
\text { average } \\
\text { rate, \% }\end{array}$ \\
\hline Ural Federal District & 187.3 & 12.39 & 189.8 & 12.41 & 183.4 & 13.42 & 186.4 & 12.73 & 187.3 & 10.65 \\
\hline Kurgan region & 215.0 & 11.61 & 205.5 & 12.26 & 199.9 & 13.19 & 195.3 & 12.60 & 194.3 & 10.58 \\
\hline Sverdlovsk region & 180.2 & 12.48 & 184.4 & 12.46 & 182.0 & 13.53 & 186.2 & 12.71 & 189.0 & 10.66 \\
\hline Tyumen region & 200.9 & 12.31 & 203.6 & 12.33 & 192.2 & 13.35 & 197.3 & 12.71 & 194.7 & 10.62 \\
\hline $\begin{array}{l}\text { including Khan- } \\
\text { ty-Mansiysk } \\
\text { Autonomous } \\
\text { Region - Yugra }\end{array}$ & 220.1 & 12.31 & 203.5 & 12.33 & 188.5 & 13.30 & 190.5 & 12.83 & 190.4 & 10.67 \\
\hline $\begin{array}{l}\text { including Yama- } \\
\text { lo-Nenets Autono- } \\
\text { mous Region }\end{array}$ & 217.0 & 11.83 & 211.3 & 11.91 & 193.5 & 13.52 & 196.3 & 12.58 & 194.7 & 10.50 \\
\hline Chelyabinsk region & 159.6 & 12.68 & 163.8 & 12.55 & 156.7 & 13.60 & 159.9 & 12.83 & 165.6 & 10.75 \\
\hline
\end{tabular}

Compiled by the author based on Rosstat data. Retrieved from: https://cbr.ru/statistics/pdko/Mortgage/ (Accessed: 02.03.2020) 
In the given period, the weighted average rate in roubles for the Ural Federal District fell by 1.74 percentage points and the weighted average mortgage period in 2014-2018 remained virtually unchanged - 187.3 months (15.6 years) (Table 3 ).

In the given period, the weighted average rate decreased in all the regions - in Kurgan region, by $1.03 \%$; in Sverdlovsk region, by $1.82 \%$; in Tyumen region, by $1.69 \%$; and in Chelyabinsk region, by $1.93 \%$. As for the mortgage period, in some regions it became longer (Sverdlovsk region, by 7.2 months and in Chelyabinsk region, by 6 months) while in Kurgan and Tyumen regions, it, on the contrary, shortened - by 20.7 months and 6.2 months respectively.

\section{Conclusion}

The study of theoretical principles and aspects of mortgage lending has led us to the following conclusions.

Our analysis of the problems and prospects of the Russian mortgage system centred around the model of mortgage lending [1]. Analysis of the three key models (balanced autonomous model or contractual savings system; truncated open model or traditional single-tier model; and expanded open model or secondary mortgage model, twotiered), characteristic of international practices of mortgage lending $[22 ; 23]$, in their relation to the Russian context has brought to light the following priorities in the development of the national system of lending relationships: first, it is essential to safeguard the interests of both lenders and borrowers; second, to enhance affordability of mortgages for average consumers and assign a priority role to mortgage lenders in the credit sector; and, finally, to enhance state regulation of mortgage lending relationships $[24 ; 25]$.

The comprehensive analysis of the primary mortgage market in the Ural Federal District has revealed the following problems.
First, in the given period, the number of participants of this market fell dramatically, in particular the number of lenders (by $32.3 \%$ ). At the end of the period, there were 23 participants. It is expected that this negative trend will have negative long-term repercussions such as a decline in competition in the banking sector and tiering of the banking system, reduced number of market niches where the right lenders could be found for investment projects (borrowers) of different risk levels.

Second, in 2014-2018, there was a steady growth of mortgage debt, which increased by 18,743 roubles (or $117.5 \%$ ). Another trend was the ageing of mortgage debt due to poor asset management, unstable financial and economic situation of borrowers caused by the changing macroand microeconomic conditions in the country.

Third, in the given period, there was a drop in the mortgage rates from $12.41 \%$ in 2014 to $10.65 \%$ in 2018, which significantly affected the real estate prices and made housing more attractive in terms of investment opportunities.

Overall, our analysis of the financial, economic, institutional and legal relations on the primary mortgage market in the Ural Federal District has demonstrated that at its current stage, the research in this sphere lacks consistency, particularly in the evaluation of the mortgage system's efficiency on the regional level.

In our further studies we intend to bridge the existing gaps in research literature by developing a methodology for systematizing the criteria and indicators of the mortgage system's efficiency. The procedure will include the following stages: creating a ranking system based on the mortgage system's efficiency criteria and the corresponding set of statistical indicators; analysis of the influence that specific statistical indicators have on the system; and, finally, developing an integral indicator for evaluation of the system's efficiency on the regional level.

\section{References}

1. Zinovieva, E.G., Vasilieva, A.G., \& Usmanova, E.G. (2018). Contemporary issues and trends in the development of the Russian national mortgage system. St Petersburg: Info-Da. (In Russ.)

2. Minz, V.M. (2012). Models of mortgage lending and prospects of their application in Russia. Bankovskoye delo, 6, 30-34. (In Russ.)

3. Pavlova, I.V. (2016). Foreign experience of mortgage lending and its applicability in Russia. Bankovskoye delo, 4, 13-19. (In Russ.)

4. Merkulov, V.V. (2013). International experience of mortgage lending and prospects of its use in Russia. St Petersburg: Piter. (In Russ.)

5. Khusikhanov, R.U. (2014). Mortgage Market Imbalances and their Influence on the Stability of the Global Financial System. Novy vzglyad. International Academic Journal, 3, 297-306. (In Russ.) 
6. Khusikhanov, R.U. (2014). Features of models of mortgage lending in the developed foreign countries. Vestnik Universiteta, 6, 164-167. (In Russ.)

7. Karimov, B.N. (2017). Mortgage lending in Russia and enhancement of its efficiency. Ekonomika i predprinimatelstvo = Journal of Economy and Entrepreneurship, 1, 12-20. (In Russ.)

8. Zinovieva, E., Kuznetsova, M., Ivashina, N., Votchel, L., \& Vikulina, V. (2018). Development of an integrated approach to the assessment of efficiency of functioning of the mortgage lending system in the Russian Federation. In: Challenging the Status Quo in Management and Economics. Strategica International Academic Conference. Bucharest, Romania, October 11-12, Sixth Edition (pp. 283-293).

9. Torluccio, G., \& Dorakh, A. (2011). Housing affordability and methodological principles: an application. International Research Journal of Finance and Economics, 79, 64-78. Available at: https:// ssrn.com/abstract=2005895.

10. Diaz-Serrano, L. (2005). Income volatility and residential mortgage delinquency across the EU. Journal of Housing Economics, 14(3), 153-177. doi: 10.1016/j.jhe.2005.07.003.

11. Kim, J. (2020). How Unsecured Credit Policies Influence Mortgage and Unsecured Loan Defaults. Journal of Money Credit and Banking. doi: 10.1111/jmcb.12620.

12. Gary-Bobo, R.J., \& Larribeau, S. (2004). A structural econometric model of price discrimination in the French mortgage lending industry. International Journal of Industrial Organization, 22(1), 101-134. doi: 10.1016/j.ijindorg.2003.07.002.

13. Diaz-Serrano, L., \& Raya, J.M. (2014). Mortgages, immigrants and discrimination: An analysis of the interest rates in Spain. Regional Science and Urban Economics, 45, 22-32. doi: 10.1016/j. regsciurbeco.2013.12.004.

14. Kau, J.B., Fang, Lu, \& Munneke, H.J. (2019). An Unintended Consequence of Mortgage Financing Regulation - a Racial Disparity. Journal of Real Estate Finance and Economics, 59, 549-588. doi: $10.1007 / \mathrm{s} 11146-018-9683-y$.

15. Becker, R., Osbom, D.R., \& Yildirim, D. (2012). A threshold cointegration analysis of interest rate pass-through to UK mortgage rates. Economic Modelling, 29(6), 2504-2513. doi: 10.1016/j. econmod.2012.08.004.

16. Courchane, M.J., Darolia, R., \& Zom, P.M. (2014). The downs and ups of FHA lending: The government mortgage roller coaster ride. Journal of Housing Economics, 24, 39-56. doi: 10.1016/j. jhe.2014.01.002.

17. Avdjiev, S., \& Hale, G. (2019). U.S. monetary policy and fluctuations of international bank lending. Journal of International Money and Finance, 95, 251-268. doi: 10.1016/j.jimonfin.2018.06.013.

18. Chen, N.-K., Chen, S.-S., \& Chou, Y.-H. (2010). House prices, collateral constraint, and the asymmetric effect on consumption. Journal of Housing Economics, 19(1), 26-37. doi: 10.1016/j. jhe.2009.10.003.

19. Klevtsov, V.V. (2017). Cooperative Building in the System of Residential Mortgage Lending. Ekonomika, 1, 18-24. (In Russ.)

20. Mamonov, M., \& Vernikov, A. (2017). Bank ownership and cost efficiency: new empirical evidence from Russia. Economic Systems, 41(2), 305-319. doi: 10.1016/j.ecosys.2016.08.001.

21. Zinovieva, E.G., \& Usmanova, E.G. (2017). The analysis of effectiveness of the primary market of mortgage loan system functioning under the Russian Federation conditions. Ekonomika i politika $=$ Economics and Politics, 2, 13-20. (In Russ.)

22. Zinovieva, E.G., \& Kuznetsova, M.V. (2017). Evaluation of the effectiveness of the primary mortgage market in the regional context. Ekonomika $i$ predprinimatelstvo = Journal of Economy and Entrepreneurship, 12-1, 222-227. (In Russ.)

23. Wood, J.D.G. (2019). Mortgage Credit: Denmark's Financial Capacity Building Regime. New Political Economy, 24(6), 833-850. doi: 10.1080/13563467.2018.1545755.

24. Zinovieva, E.G., Koptyakova, S.V., \& Usmanova, E.G. (2019). Complex approach to the estimation of the efficiency of functioning of the mortgage loaning system in the Russian Federation. Menedzhment $v$ Rossii i za rubezhom = Management in Russia and Abroad, 2, 54-62. (In Russ.)

25. Yanova, S.Y., \& Popova, E.M. (2018). Monetary policy: result or momentum economic development. Izvestiya Sankt-Peterburgskogo gosudarstvennogo ekonomicheskogo universiteta, 5, 54-63. (In Russ.) Available at: https://elibrary.ru/item.asp?id=36334806. 


\section{Information about the authors}

Ekaterina G. Zinovyeva - Associate Professor, Nosov Magnitogorsk State Technical University (38 Lenina av., Magnitogorsk, 455000, Russia); e-mail: ekaterina_7707@mail.ru

Natalya R. Balynskaya - Associate Professor, Nosov Magnitogorsk State Technical University (38 Lenina av., Magnitogorsk, 455000, Russia); e-mail: balynskaya@list.ru

Svetlana V. Koptyakova - Associate Professor, Nosov Magnitogorsk State Technical University (38 Lenina av., Magnitogorsk, 455000, Russia); e-mail: svetlana.cop@yandex.ru

Oksana O. Akhmetzianova - Researcher, University of Science and Technology of China (96, JinZhai Road Baohe District, Hefei, Anhui, 230026, China); e-mail: oksanochka-star@mail.ru

ARTICLE INFO: received December 7, 2019; accepted March 05, 2020

\section{Информация об авторах}

Зиновьева Екатерина Георгиевна - доцент, Магнитогорский государственный технический университет им. Г.И. Носова (455000, Россия, Магнитогорск, пр. Ленина, 38); e-mail: ekaterina_7707@mail.ru

Балынская Наталья Ринатовна - доцент, Магнитогорский государственный технический университет им. Г.И. Носова (455000, Россия, Магнитогорск, пр. Ленина, 38); e-mail: balynskaya@list.ru

Коптякова Светлана Владимировна - доцент, Магнитогорский государственный технический университет им. Г.И. Носова (455000, Россия, Магнитогорск, пр. Ленина, 38); e-mail: svetlana.cop@yandex.ru

Ахметзянова Оксана Олеговна - исследователь, Научно-технический университет Китая, Хэфэй, Китай (230026, КНР, Хэфэй, ул. Цзиньчжай, 96); e-mail: oksanochka-star@mail.ru

ИНФОРМАЦИЯ О СТАТЬЕ: дата поступления 7 декабря 2019 г.; дата принятия к печати 5 марта 2020 г. 